\title{
SARS-CoV-2 and pulmonary embolism: who stole the platelets?
}

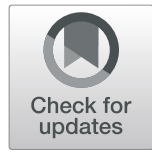

\author{
Michael Tran ${ }^{*}$, Chirag Sheth ${ }^{1}$, Rohan Bhandari ${ }^{1}$ Scott J. Cameron ${ }^{2}$ (D) and Deborah Hornacek ${ }^{1}$
}

\begin{abstract}
Background: Patients infected with SARS-CoV-2 often develop venous and arterial thrombosis. The high patient mortality is partly attributed to thrombotic events. An emerging trend is the presence of immunological phenomena including antiphospholipid antibodies which may promote thrombosis. The mechanism for these observations is not clear though many patients with SARS-CoV-2 develop thrombocytopenia.

Case presentation: We describe a patient with SARS-CoV-2 pneumonitis who presented with intermediate risk pulmonary embolism (PE). Careful attention to his daily platelet count suggested the possibility of immune mediated heparin-induced thrombocytopenia (HIT) which was confirmed by laboratory testing and resolved when anticoagulation was switched to a direct thrombin inhibitor.
\end{abstract}

Conclusions: Since excessive platelet activation and in situ thrombosis occur in HIT, this case underscores the need to consider that thrombocytopenia in patients with SARS-CoV-2 - most of whom receive heparinoids - may be unrecognized HIT. A central role for the platelet in the etiology of thrombosis during the COVID-19 pandemic should be explored.

Keywords: Pulmonary embolism, HIT, SARS-CoV-2, COVID-19, Thrombosis, Heparin

\section{Background}

Critically ill patients with COVID-19 infection often have multiple abnormalities in hemostasis and thrombosis. Recent literature documents hematologic derangements including mild thrombocytopenia [1], elevated d-dimer [2], prolonged activated partial-thromboplastin time (aPTT), and disseminated intravascular coagulation (DIC) [3]. It is unclear whether these changes reflect SARS-CoV-2 infection, or an inflammatory state of acute illness. The recent medical literature reports multiple anticoagulation strategies to prevent thrombotic events in patients infected with SARS-CoV-2. Emerging reports suggest the possibility of HIT developing in SARS-CoV-2 patients receiving heparin anticoagulation $[4,5]$. This case was a diagnostic

\footnotetext{
*Correspondence: TRANM2@ccf.org

'Heart Vascular and Thoracic Institute, Department of Cardiovascular

Medicine, Section of Vascular Medicine, Cleveland Clinic Foundation, Desk

J-35, Cleveland Clinic Foundation, Cleveland, OH 44195, USA

Full list of author information is available at the end of the article
}

dilemma since both thrombocytopenia and in situ pulmonary thrombosis are common features of SARS-CoV-2 infection [6], making less common diagnoses, such as HIT, which shares similar features, more challenging to diagnose.

\section{Case presentation}

A 62-year-old man with type 2 diabetes mellitus presented to the emergency department (ED) with 4-day history fever, cough, and dyspnea. The patient's vitals in the ED were as follows: Temperature $39.2^{\circ} \mathrm{C}\left(102.6^{\circ} \mathrm{F}\right)$, blood pressure $167 / 67 \mathrm{mmHg}$, heart rate 135 beats per min, respiratory rate 22 breaths per minute, oxygen saturation $74 \%$ on room air. The $\mathrm{SaO}_{2}$ improved to $96 \%$ with oxygen therapy at 10 $\mathrm{L} /$ minute by non-rebreather mask. Relevant laboratory data was as follows: white blood count $13.9 \mathrm{~K} / \mathrm{uL}$, platelet $412 \mathrm{~K} /$ $\mathrm{uL}$, sodium $126 \mathrm{mmol} / \mathrm{L}$, creatinine $0.7 \mathrm{mg} / \mathrm{dL}$. Chest radiography showed bilateral diffuse patchy airspace opacities. There was concern for COVID-19 which was confirmed by 
polymerase chain reaction (PCR) for the SARS-CoV-2 amplicon. The patient developed hypoxemic respiratory failure the following day and was placed on mechanical ventilation. Over a 10-day time period, the patient was treated with investigational therapies for COVID-19 including azithromycin, hydroxychloroquine, and convalescent plasma. The anticoagulation regimen consisted of subcutaneous enoxaparin (60 mg once daily) for venous thromboembolism (VTE) prophylaxis. Intravenous unfractionated heparin (UFH) flushes were used to maintain patency of vascular access. The patient was subsequently transferred to our tertiary medical center on hospital day 12 for further management.

Bedside echocardiography suggested right ventricular (RV) dilation, raising the possibility of pulmonary embolism (PE). Venous Duplex of the lower extremities was unremarkable. Chest computed tomography angiography (CTA) demonstrated right upper lobe lobar and segmental PE (Fig. 1). Relevant laboratory data included hemoglobin $11.1 \mathrm{~g} / \mathrm{dL}$, platelets $487 \mathrm{k} /$ $\mathrm{uL}$, creatinine $0.93 \mathrm{mg} / \mathrm{dL}$, pro-BNP $7600 \mathrm{pg} / \mathrm{mL}$, troponin $\mathrm{T}<0.01 \mathrm{ng} / \mathrm{mL}$, d-dimer $11,040 \mathrm{ng} / \mathrm{mL}$, activated partial thromboplastin time (aPTT) $24.2 \mathrm{~s}$, prothrombin time (PT) $14 \mathrm{~s}$, fibrinogen $661 \mathrm{mg} / \mathrm{dL}$. The patient had an equivocal cardiolipin IgM antibody of 15 IgG phospholipid units (MPL) since our reference range is $<12 \mathrm{MPL}$, and beta-2 glycoprotein antibodies were negative. Using the patient's PT, d-dimer, and measured fibrinogen concentration of $661 \mathrm{mg} / \mathrm{dL}$ his DIC score is 6 which was compatible with overt DIC.

A multidisciplinary pulmonary embolism response team (PERT) reviewed the patient's case and recommended therapeutic anticoagulation with intravenous

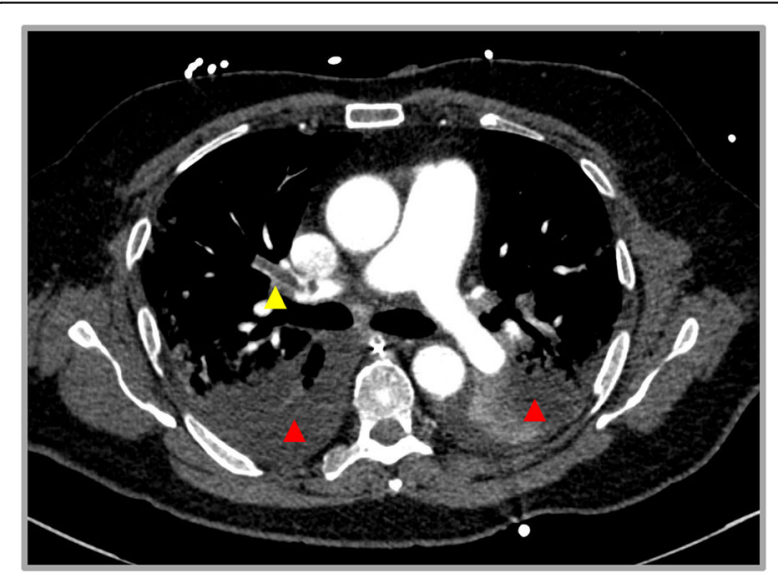

Fig. 1 Computed tomography (CT) of chest showing a filling defect in the right upper labor pulmonary artery extending into the segmental and subsegmental pulmonary branches consistent with an acute pulmonary embolism (yellow arrowhead). Patchy infiltrates are indicated by the red arrowhead
UFH dosed at 18 units $/ \mathrm{kg} / \mathrm{hr}$ and monitored by the anti-Xa chromogenic assay. The patient's platelet count decreased from $487 \mathrm{k} / \mathrm{uL}$ to a nadir of $91 \mathrm{k} / \mathrm{uL}$ over the following 4 days, raising the concern for heparin induced thrombocytopenia (HIT) with an intermediate pretest probability by the $4 \mathrm{Ts}$ score of 4 (Table 1). Heparin products were exchanged for the direct thrombin inhibitor (DTI) bivalirudin dosed at $0.19 \mathrm{mg} / \mathrm{kg} / \mathrm{hr}$ and monitored with activated partial thromboplastin time with a goal of 46 to $65 \mathrm{~s}$. IgG specific anti-platelet factor 4 (PF4)-heparin enzyme linked immunosorbent assay (ELISA) was quite positive (optical density 1.08 , normal value $<0.4$ ). The heparin induced platelet aggregation (HIPA) functional assay was also positive, confirming the diagnosis of HIT. The patient's platelet count increased to $279 \mathrm{k} / \mathrm{uL}$ three days after the discontinuation of UFH (Fig. 2). The patient responded favorably to anticoagulation with a DTI without new thrombotic complications.

HIT is an acquired immune-mediated complication associated with UFH or LMWH administration in which platelets become haptenized $[7,8]$, creating a prothrombotic state that can be limb- or lifethreatening due to venous or arterial thrombosis. The most common clinical manifestation of HIT is thrombocytopenia (platelet count $<150 \mathrm{k} / \mathrm{uL}$ ) in $85-$ $90 \%$ of patients between 5 and 10 days after initiating heparin products. The incidence of HIT is $<0.1-7 \%$ depending on clinical context, the heparin product used, and duration and dose of exposure $[8,9]$.

HIT develops when immunoglobulin G (IgG) antibodies recognize PF4-heparin complexes and activate platelet surface $\mathrm{Fc} \gamma$ receptors. This step activates platelets which degranulate and aggregate as thrombi [10]. Laboratory evaluation includes an IgG-specific anti-PF4 immunoassay which has high sensitivity but sometimes low specificity for activated platelets. Interestingly, this assay also detects non-platelet activating anti-PF4/heparin antibodies [11]. The diagnosis is supported by demonstrating IgG anti-PF4-heparin mediated platelet activation using washed platelets with functional assays such as the HIPA and

Table 1 4Ts Score for Heparin-Induced Thrombocytopenia

\begin{tabular}{lll}
\hline 4Ts pretest probability & Score & 4 \\
\hline Thrombocytopenia & $\begin{array}{l}\text { Platelet count fall > 50\% and platelet } \\
\text { nadir }>20\end{array}$ & 2 \\
Timing of platelet count fall & $\begin{array}{l}\text { Onset after day 10 of heparin } \\
\text { exposure }\end{array}$ & 1 \\
$\begin{array}{l}\text { Thrombosis or other } \\
\text { sequelae }\end{array}$ & No new thrombosis \\
$\begin{array}{l}\text { Other causes for } \\
\text { thrombocytopenia }\end{array}$ & Possible other causes \\
\hline
\end{tabular}




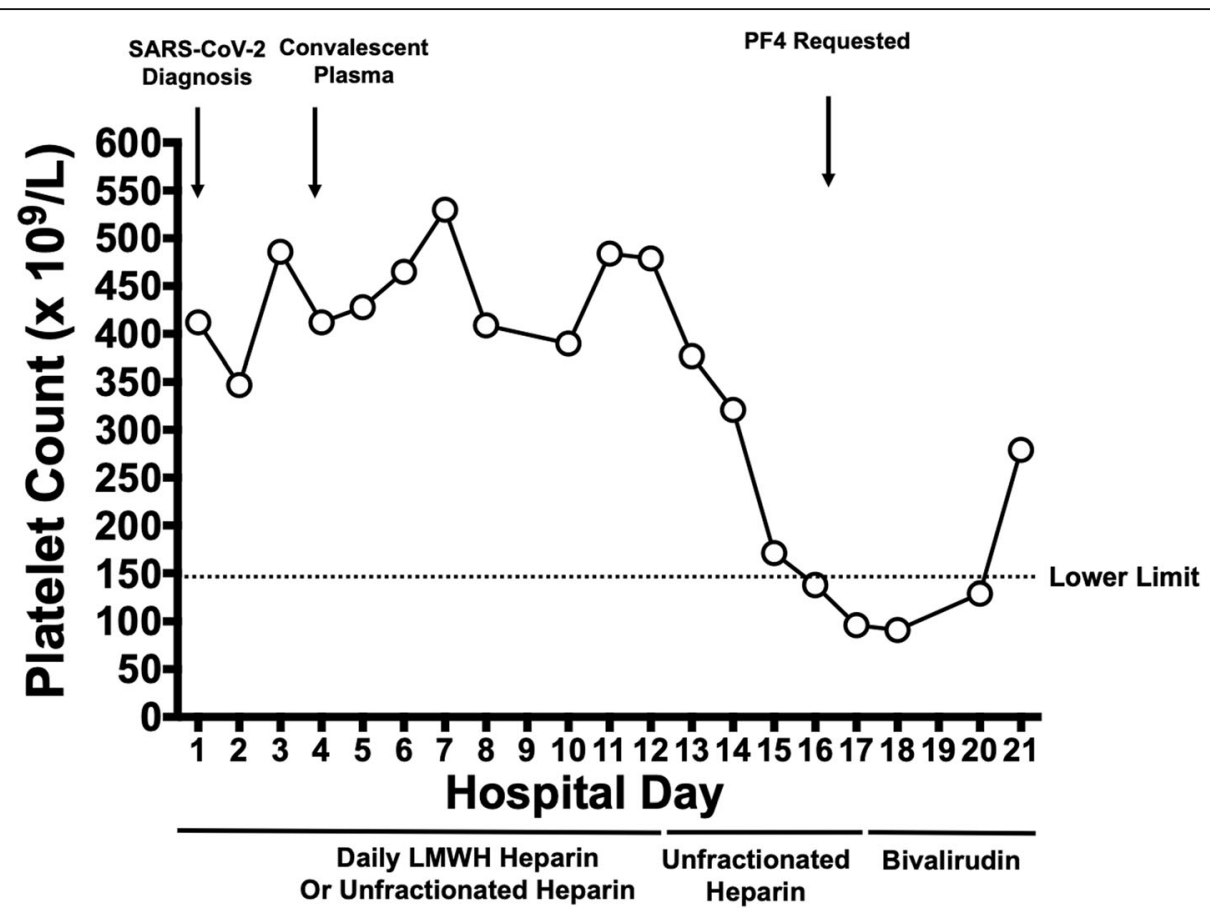

Fig. 2 Platelet count and time points for anticoagulation administration and laboratory testing

serotonin release assay (SRA) [12]. The assay performance of these two offers superior sensitivity and specificity in detection of pathogenic platelet activating antibodies. As a clinicopathologic syndrome, the diagnosis of HIT depends on taking a careful history and having temporal awareness of the exposure to heparinoids [13].

\section{Conclusions}

It is clear that patients infected with SARS-CoV-2 have unusual immunological phenomena including the presence of anti-phospholipid antibodies [14, 15]. The training of the internist is instinctually drawn to a broad differential diagnosis which is now more important than ever in the COVID-19 era. Early recognition and treatment for other immunologic phenomena such as HIT should be considered for every patient since thrombosis with thrombocytopenia often co-exist. Further study is required to determine if undiagnosed HIT contributes to the dramatically high number of thrombotic events in patients with SARS-CoV-2 infection.

\section{Authors' contributions}

All authors participated in writing of the manuscript and have reviewed and approved the submitted version.

\section{Funding}

This study was not supported by external funds.
Availability of data and materials

The datasets obtained and analyzed in the current study are available from the corresponding author on reasonable request.

Ethics approval and consent to participate

Ethics approval was waived given there is no unique, identifiable information, and case reports do not require ethical approval in the United States. Our report adheres to the Ethical Guidelines for Medical and Health Research Involving Human Subjects established by the government Unites States.

Ethics approval

No identifiable information or unique patient data is included.

\section{Competing interests}

None.

\section{Author details}

${ }^{1}$ Heart Vascular and Thoracic Institute, Department of Cardiovascular Medicine, Section of Vascular Medicine, Cleveland Clinic Foundation, Desk J-35, Cleveland Clinic Foundation, Cleveland, OH 44195, USA. ${ }^{2}$ Department of Cardiovascular and Metabolic Sciences. Cleveland Clinic Lerner College of Medicine, Cleveland, OH 44195, USA.

Received: 22 May 2020 Accepted: 21 July 2020

Published online: 03 September 2020

\section{References}

1. Lippi G, Plebani M, Henry BM. Thrombocytopenia is associated with severe coronavirus disease 2019 (COVID-19) infections: A meta-analysis. Clinica chimica acta. 2020;506:145-8

2. Lippi G, Favaloro EJ. D-dimer is associated with severity of coronavirus disease 2019: a pooled analysis. Thromb Haemost. 2020;120(05):876-8.

3. Tang N, Li D, Wang X, Sun Z. Abnormal coagulation parameters are associated with poor prognosis in patients with novel coronavirus pneumonia. J Thromb Haemost. 2020;18(4):844-7.

4. Liu X, Zhang X, Xiao Y, Gao T, Wang G, Wang Z, et al. Heparin-induced thrombocytopenia is associated with a high risk of mortality in critical 
COVID-19 patients receiving heparin-involved treatment. medRxiv. 2020: 20076851.

5. Riker RR, May TL, Fraser GL, Gagnon DJ, Bandara M, Zemrak W, et al. Heparin-induced Thrombocytopenia with Thrombosis in COVID-19 Adult Respiratory Distress Syndrome. Res Pract Thromb Haemost. 2020. https://doi. org/10.1002/rth2.12390

6. Wichmann D, Sperhake J-P, Lütgehetmann M, Steurer S, Edler C Heinemann A, et al. Autopsy findings and venous thromboembolism in patients with COVID-19. Ann Intern Med. 2020

7. Amiral J, Bridey F, Dreyfus M, Vissoc AM, Fressinaud E, Wolf M, et al. Platelet factor 4 complexed to heparin is the target for antibodies generated in heparin-induced thrombocytopenia. Thromb Haemost. 1992;68(1):95-6.

8. Warkentin TE, Sheppard J-Al, Horsewood P, Simpson PJ, Moore JC, Kelton JG. Impact of the patient population on the risk for heparin-induced thrombocytopenia. Blood. 2000:96(5):1703-8.

9. Martel N, Lee J, Wells PS. Risk for heparin-induced thrombocytopenia with unfractionated and low-molecular-weight heparin thromboprophylaxis: a meta-analysis. Blood. 2005;106(8):2710-5.

10. Greinacher A, Eichler P, Lubenow N, Kwasny H, Luz M. Heparin-induced thrombocytopenia with thromboembolic complications: meta-analysis of 2 prospective trials to assess the value of parenteral treatment with lepirudin and its therapeutic aPTT range. Blood. 2000:96(3):846-51.

11. WARKENTIN TE, Greinacher A, Gruel Y, Rh A, Bh C, scientific obot, et al. Laboratory testing for heparin-induced thrombocytopenia: a conceptual framework and implications for diagnosis. J Thromb Haemost. 2011;9(12): 2498-500.

12. Chong BH, Burgess J, Ismail F. The clinical usefulness of the platelet aggregation test for the diagnosis of heparin-induced thrombocytopenia. Thromb Haemost. 1993;69(04):344-50.

13. Warkentin TE. Laboratory diagnosis of heparin-induced thrombocytopenia. Int J Lab Hematol. 2019;41(S1):15-25.

14. Zhang Y, Xiao M, Zhang S, Xia P, Cao W, Jiang W, et al. Coagulopathy and Antiphospholipid antibodies in patients with Covid-19. N Engl J Med. 2020; 382(17):e38.

15. Bowles L, Platton S, Yartey N, Dave M, Lee K, Hart DP, et al. Lupus anticoagulant and abnormal coagulation tests in patients with Covid-19. N Engl J Med. 2020.

\section{Publisher's Note}

Springer Nature remains neutral with regard to jurisdictional claims in published maps and institutional affiliations.

Ready to submit your research? Choose BMC and benefit from:

- fast, convenient online submission

- thorough peer review by experienced researchers in your field

- rapid publication on acceptance

- support for research data, including large and complex data types

- gold Open Access which fosters wider collaboration and increased citations

- maximum visibility for your research: over $100 \mathrm{M}$ website views per year

At $\mathrm{BMC}$, research is always in progress.

Learn more biomedcentral.com/submissions 